\title{
G

\section{The Choice of Foreign Market Entry Modes: The Role of Resources and Industrial Driving Forces ${ }^{1}$}

\author{
Andrea S. Gubik, Sándor Karajz
}

\begin{tabular}{|c|c|}
\hline \multirow{2}{*}{\multicolumn{2}{|c|}{$\begin{array}{l}\text { Objective: The objective of the paper is to analyse the effects of corporate resources, } \\
\text { attitudes of owner/entrepreneur/manager to internationalisation and the } \\
\text { characteristics of the business industry on the entry mode choice. }\end{array}$}} \\
\hline & \\
\hline \multicolumn{2}{|c|}{$\begin{array}{l}\text { Research Design \& Methods: Based on factor and cluster analyses the authors } \\
\text { highlight the latent structure lying behind different variables and find typical groups } \\
\text { of companies matching the identified factors. }\end{array}$} \\
\hline \multicolumn{2}{|c|}{$\begin{array}{l}\text { Findings: Providing physical resources and access to appropriate information is } \\
\text { necessary, but not sufficient. The attitude of the owner/entrepreneur/manager to } \\
\text { internationalisation should be improved as well so that they will be able to appear } \\
\text { and operate successfully in international markets. }\end{array}$} \\
\hline \multicolumn{2}{|c|}{$\begin{array}{l}\text { Implications \& Recommendations: Giving the right place to subjective matters in } \\
\text { promoting internationalisation may contribute to the increase in corporate } \\
\text { participation in different support programs. }\end{array}$} \\
\hline \multicolumn{2}{|c|}{$\begin{array}{l}\text { Contribution \& Value Added: On the basis of the obtained findings, different ways of } \\
\text { how support programs can promote the companies' international activities and } \\
\text { strengthen their commitments to achieving higher added values can be defined. }\end{array}$} \\
\hline & \\
\hline & \\
\hline & \\
\hline
\end{tabular}

\section{Suggested citation:}

Gubik, A.S. \& Karajz, S. (2014). The Choice of Foreign Market Entry Modes: The Role of Resources and Industrial Driving Forces. Entrepreneurial Business and Economics Review, 2(1), 49-63.

\footnotetext{
1 The article came into being within the project no. StG-21310034 entitled 'Patterns of Business Internationalization in Visegrad Countries - In Search for Regional Specifics' financed by International Visegrad Fund, coordinated by Cracow University of Economics and conducted in the years 2013-2014.
} 


\section{INTRODUCTION}

Companies engaged in international activities perform better, grow faster and are more innovative than those without international activities (EC, 2010). In addition, they invest more in fostering knowledge development of the employed, mainly in the form of internal and external training programmes, courses, and language learning (Gubik, 2011).

International business activities enable companies to enter larger markets, obtaining larger economies of scale, decrease costs, raise capital and get access to advanced technologies, which results in the increase of their competitiveness. Overcoming larger geographic distances is getting easier and easier due to shorter supply periods, a wider range of possible solutions and increased communication effectiveness and efficiency. Thus, entering international markets has become easier. In addition, the listed factors create international competitive environment and affect companies without international activities in every sector of industry. It is obvious that the geographic distance is not the only distance that has to be considered. Mention should be made of other dimensions like cultural differences, language barriers, differences in educational and political systems (Johanson \& Wiedersheim, 1975).

It is a well-established fact that the larger the company size is, the better opportunities this company has to enter international markets and the more complex solutions it is likely to apply (Observatory of European SMEs, 2007; EC, 2010). The scale and the scope of company's business activities also influence its internationalisation. However, its boundaries are continually changing. For instance, the retail sector used to have a fixed place of business but e-commerce activities have completely changed the situation.

Both the size of the domestic market and the company's proximity to a national border also affect the company's level of international activity. The probability of international activities even of the smallest firms with a market power of several kilometres increases if these firms are located close to the national border. The proximity of companies to the national border increases their international exposure, whereas their international activities are not restricted to the neighbouring country (Dimitratos, 2002). The smaller a country is, the more internationalised its companies are (EC, 2010). The proximity of the national border can be considered a competitive advantage that can be utilised more efficiently by ensuring appropriate resources and creating an international business environment (Gubik, 2011).

\section{LITERATURE REVIEW}

There are several basic models of the internationalisation process. One group of models emphasize the gradualism in the internationalisation process. This perspective includes Uppsala model (Johanson \& Vahlne, 1977; 1990) according to which the engagement in international activities evolves gradually and is a cumulative and coherent, path-dependent process (Erikkson et al., 1997). In the first stage, when a company has insufficient knowledge of the market and partners operating in it, it chooses a simple form of appearance in the market (for example, export). Later, due to its accumulated experience, the company transforms into a more complex form (for example, sets up 
a subsidiary). This model cannot be applied to large companies, since they have an easy access to all types of resources (including managerial experience and knowledge). The export development models, such as the Reid export behaviour model (Reid, 1981), also emphasize the gradual character of the company's internationalisation process. However, they primarily analyse decision-making processes in terms of export activities and main factors related to this.

The results of empirical research conducted in this issue indicate that Hungarian companies adopt gradual internationalisation (Antalóczy \& Éltető, 2002; Szerb \& Márkus, 2008).

In the 1990s alongside the Uppsala and export models of gradual internationalization, a new group of companies emerged, which rapidly broke into international markets (born-global enterprises). Born global firms exist mainly in new knowledge-intensive industries (Rasmussen \& Madsen, 2002; Criado et al., 2002). As for their size, they are mostly micro- and small-sized enterprises. About one-fifth of young enterprises in Europe are born globals but with considerable differences among countries (Eurofound, 2012), in Hungary this rate is less than $10 \%$.

According to some researchers, it would be a mistake to examine companies outside the context they operate in (Granovetter, 2005). As for internationalisation, there is a general consensus that apart from personal experience and professional knowledge of company managers, social and economic networks created around companies also play a key role in decision-making processes. The results of the conducted research encompassing large companies indicate that apart from corporate human capital, the relationship capital also plays a crucial role in internationalisation (Hitt et al., 2006). Some researchers think that the number of decision makers is of determining importance in terms of internationalisation as well (Clercq \& Bosma, 2004). They consider that the more decision makers are involved, the more networks they can access to, the more experience they can gain and the more knowledge they can generate.

\section{MATERIAL AND METHODS}

The data were obtained from empirical research within the framework of the Visegrad Fund project "Patterns of business internationalization in Visegrad countries - in search for regional specifics" (standard grant no. 21310034) conducted in the late 2013 and early 2014. The questionnaire was available online.

\section{The Sample}

The Hungarian database contains responses of 104 companies out of which 74 were active in international markets. Approximately $26 \%$ of companies were micro-sized enterprises, $30 \%$ were small-sized enterprises, and $21 \%$ were middle-sized companies and $23 \%$ were large companies. The sample does not represent Hungarian companies since this was not the purpose of the data collection. This is because a sample with the same ratio of different company size groups would have encompassed mainly microsized enterprises, which were less active internationally and would have been less suitable for achieving the goals of the research. The purpose of this survey was to include the same amount of companies of different sizes in the research, that's why large and 
internationally active companies are over-represented in it. When evaluating the results of this paper we have to consider this fact because it may decrease the generalizability and applicability of the results.

In our database 87 companies are owned by Hungarian investors and 8 companies are in foreign ownership with $100 \%$ share. As for the business activities of the surveyed companies, almost half of them are industrial companies (49\%), 35\% are service providers, $14 \%$ are trading companies and $2 \%$ are involved in agricultural activities. Almost $44 \%$ are actively present in the EU and other international markets. Out of $49 \%$ companies which are without international activities, $17 \%$ conduct business activities in the local markets (Figure 1).

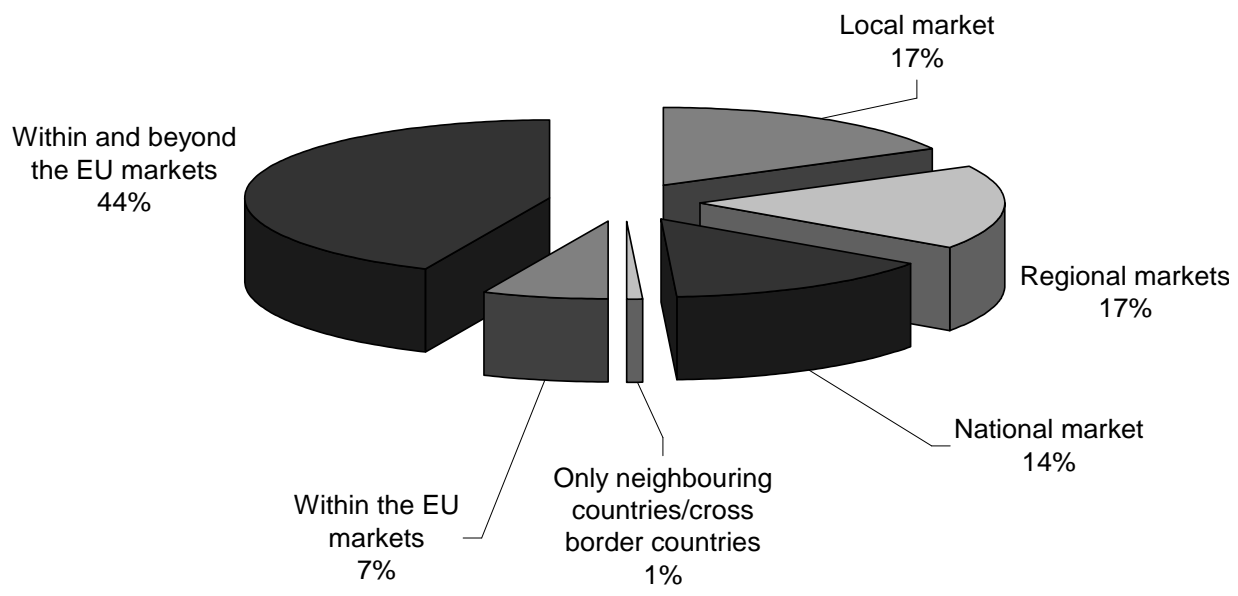

Figure 1: Firms' territorial scope

Source: own elaboration $(n=104)$.

\section{Conceptualisation and Operationalisation}

Internationalisation is a process of direct or indirect involvement of enterprises in international transactions. International activities can have several modes, the most simple of which is export.

There are two ways of exporting, namely, indirect exporting and direct exporting. Indirect exporting does not involve direct contact of the company with its buyers, sellers or business partners. A typical example for this is the service provided by export agents, export/import brokers, export management companies or companies involved in export trade.

- An export agent is a firm (or an individual) in the country of the exporting company that assists in locating customers, conducting negotiations, etc.,

- an export/import broker provides assistance in concluding business deals without being directly involved in sales or purchasing,

- an export management company is an independent intermediary that specialises by product, countries or regions and manages export activities of companies in a complex way, 
- export trading company is also an independent intermediary and provides similar services to those of an export management company, but it operates primarily an a demand-driven basis and offers customer-tailored supplies.

In case of direct exporting companies utilize the assistance of their own foreign agents, distributors and branch offices in order to manage exporting processes.

Cooperative exporting is implemented via export consortium, clustering and piggybacking. Piggyback exporting is a practice when one company get access to an export market using the distribution channels of another company.

Contractual solutions encompass contract management solutions, assembling contracts (e.g. repairing, maintenance, training programs, product consultancy and installation of machine parts), manufacturing contracts (e.g. supply), turnkey contracts, international licenses and international franchise.

Another mode of internationalisation is direct investment, which enables companies to get access to international markets whilst retaining control. One of the solutions of this can be opening an office in another country, setting up a joint venture or establishing a wholly-owned subsidiary.

Different foreign market entry modes are diverse in many respects, like: scope of capital commitment, scope of management commitment, scope of control, scope of risk, scope of potential profits, scope of input costs (Daszkiewicz \& Wach, 2012).

Decisions about foreign market entry mode depend on several aspects which are influenced by objective company characteristics (the size and scope of business activities), environmental characteristics (industry characteristics, networks, nature and strength of competition, etc.) and objective and subjective factors related to decisionmakers (attitudes, motivations, experience, plans, etc.).

The purpose of this paper is to find out whether the following factors affect the mode of entry choice into foreign markets and in what way they work:

- the amount and type of available corporate internal resources,

- the attitude of owner/entrepreneur/manager to internationalisation,

- basic characteristics of business industry in which the firm operates.

Two questions related to the mode of international activity of companies from the questionnaire were used to investigate this issue: 'What kind of international activities are you engaged in? (more than one answer is possible)' and 'If you implemented more than one entry mode, what was the pattern of their implementation?'

The availability of resources, the attitude of owner/entrepreneur/manager to internationalisation and the market characteristics were mapped with a rating from one to five on the Likert scale. As for the resources, the respondents evaluated the available financial resources for internationalisation (e.g. equity and venture capital, credits), human resources for internationalisation (the employees' appropriate foreign language knowledge, experience gained in foreign markets, awareness of different business cultures and cultural differences), physical resources for internationalisation (e.g. equipment, know-how, innovation) and the necessary information resources for internationalisation (knowledge of international markets).

When the respondents evaluated the attitude of owner/entrepreneur/manager to internationalisation, they scored their motivation to go international, cosmopolitanism 
and international openness, knowledge of international markets, experience gained in international markets and their professional business experience in general.

When the respondents evaluated the basic characteristics of the business industry in which their firm operated, they scored the company's vulnerability towards internationalization (e.g. the local kiosk is certainly local, some hi-tech industries are certainly global that is internationally vulnerable), the level of competitiveness in general (Do firms compete strongly?); intensiveness of foreign competitors (Are there many foreign competitors in your industry?); intensiveness of foreign capital (Is your industry dominated by foreign capital?); level of innovation (Do the firms in your industry implement much innovation?)

\section{Research Hypotheses}

Theories on internationalisation justify the determining role of resources in internationalisation. The transaction cost theory can help companies to choose a foreign market entry mode (Anderson \& Gatignon, 1986). The importance of human resources, like the employees' appropriate foreign language knowledge and experience in foreign markets (Hitt et al., 2006) and experiential knowledge (Barkema et. al, 1996; Erramilli, 1991 ) is also indisputable. The required physical (e.g., equipment, know-how, innovation) and information resources also play an essential role in decision-making processes on internationalisation and especially on foreign market entry modes.

H1: The type and scope of corporate resources affect the foreign market entry mode. The more resources raised from international activities a company has, the more complex solutions it applies.

If a company wishes to evaluate business opportunity, first it should be able to identify this opportunity. The attitude of owner/entrepreneur/manager to internationalisation considerably determines the material and physical aspects of the decision (e.g., the availability of financial resources). Presumably, elements determining professionalism, competence and expertise (e.g. experience) weigh more in corporate internationalisation. The ability to understand and adopt unfamiliar values and expectations of different cultures is also essential (Horská \& Krasnodębski, 2009).

The attitude to internationalisation can be explained by internal and external factors (Perlitz, 2004). Besides internal personal commitments to internationalisation, external market forces have a considerable impact on this process. A good example is the principle of 'follow the market leader' developed in the theory of oligopoly markets (Stackelberg, 1952) that affects and determines the international orientation of the owner/entrepreneur/manager. Thus, the attitude of decision makers to international activities plays a determining role in the internationalisation process.

H2: The attitude of owners, entrepreneurs and managers to internationalisation (motivation, approach and knowledge) channels internationalisation in a positive direction.

We suppose that the stronger competition the sectors of economy experience and the more market competitors they have, the more likely they are to become active in the international market and the more complex solutions they are interested to implement. 
Abrahamczik (2012) justifies the impact of competition intensity on internationalisation and corporate success in the international market.

The availability of foreign capital in the sectors under investigation also has a favourable effect on internationalisation. Finally, a high level of innovation considerably contributes to the company's becoming international and to implementing more and more complex solutions (EC, 2010).

H3: Sector characteristics (competition intensity, number of foreign competitors, intensiveness of foreign capital, level of innovation) affect modes of international activities.

\section{RESULTS AND DISCUSSION}

The figures obtained in the survey show that $71 \%$ of the surveyed companies are present in the international market in some form. Approximately $51 \%$ are engaged in importing; $25 \%$ conduct indirect export activities; $38.5 \%$ are involved in direct exporting and a low proportion of them (12.5\%) have cooperative export activities. The rate of those who seek contractual solutions such as: supply, license or franchise amounts to $41.3 \%$. There are some (21.5\%) who have foreign investments (Figure 2 ).

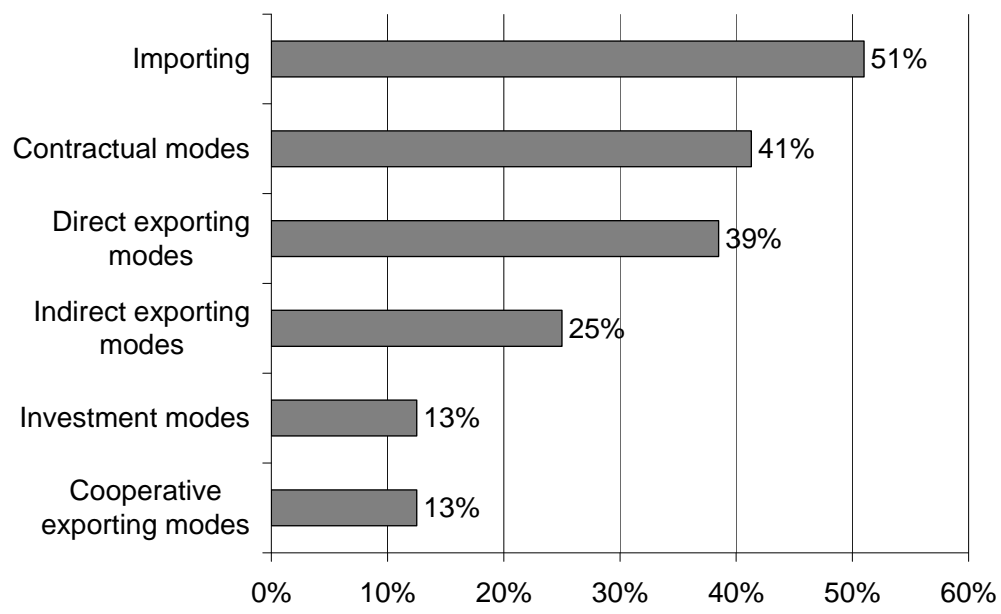

Figure 2. Modes of international activities

Source: own elaboration $(n=104)$.

A considerable proportion of companies are engaged in more than one international activity. An intensity indicator has been elaborated to measure internationalisation. It indicates how many possible foreign market entry modes a company has utilised during its international activities. The indicator ranges from 0 to 1 , where 0 means that the company does not conduct activities in international markets and 1 means engagement in all activity types (import, direct export, indirect export, cooperative export, contractual modes and investment). The indicator mean of 0.3 indicates that companies utilise about one-third of their opportunities for internationalisation. 
There are divergences in terms of size and activity areas. There is no clear direct relation between the growing corporate size and the increasing internationalisation intensity. Small and medium-sized enterprises are the most active with a 0.35 intensity indicator, in contrast to large and micro-sized companies with 0.28 and 0.22 indicators respectively.

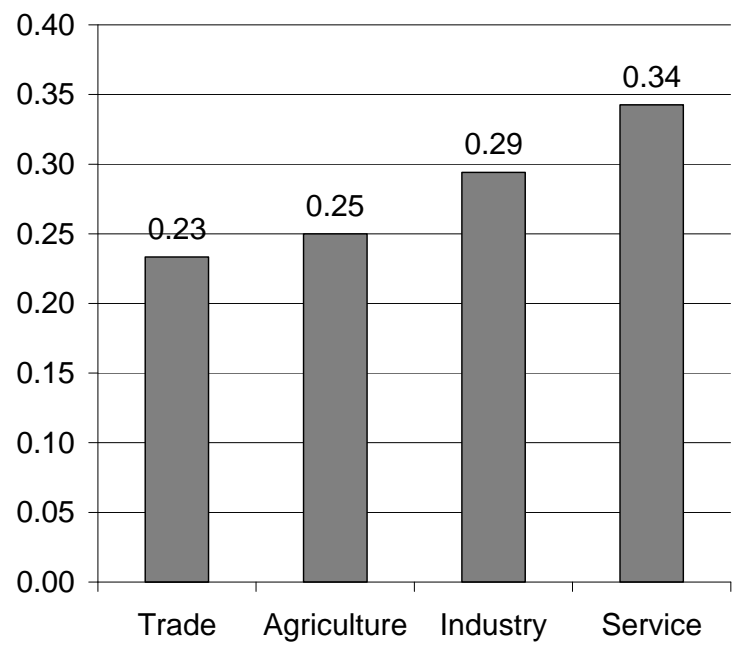

Figure 3. Internationalisation intensity by activity areas Source: own elaboration $(n=104)$.

As for their activity areas, there are only slight divergences. Trading companies are characterised by the lowest intensity which are followed by industrial companies and service providers (Figure 3). Only two companies are engaged in agricultural activities.

We went international immediately (or within 1-2 years of the firm foundation), we tried to operate on many international markets despite the distance

We still use only one entry mode

We started from simple exporting and later tried to implement more advanced entry modes

We went international immediately (or within 1-2 years of the firm foundation), but only to neighbouring countries or CEEC countries

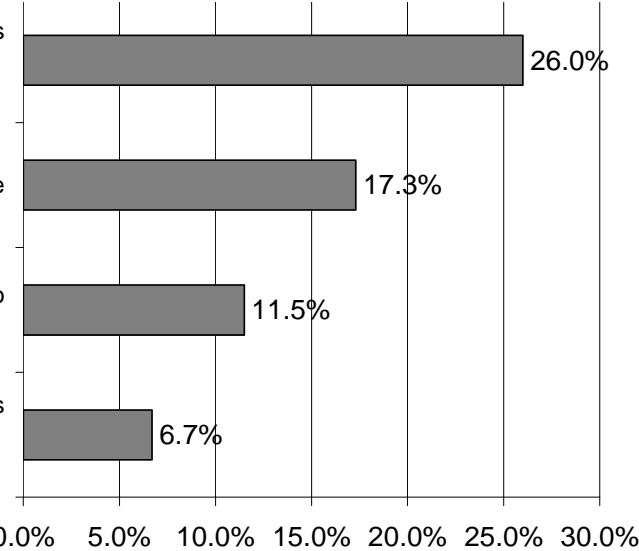

Figure 4. Patterns of foreign market entry

Source: own elaboration $(n=104)$. 
While $17 \%$ of respondents chose only one foreign market entry mode, $12 \%$ focused on gradual internationalisation (Johanson \& Vahlne, 1990), during which the more complex types in entering international markets appeared gradually and followed simple solutions. The proportion of companies which became immediately active accounts for $33 \%$. Only $7 \%$ of them were present in the markets of neighbouring countries or Central and Eastern Europe, whereas $26 \%$ targeted distant international markets (Figure 4).

First, the impact of resources related to international activities were analysed with the intensity indicator elaborated for measuring internationalisation. The first table clearly illustrates the significant correlation between the availability of resources for internationalisation and the internationalisation intensity indicator (Spearman's Rho values exceed $0.45, p=0.000$ ). The more resources are available, the more intensive internationalisation is. The marked resource types (financial, human, physical and information) also correlate with each other. The companies either have a sufficient amount of them or lack all of them.

Table 1. Relationship between foreign market entry modes and corporate internal resources

\begin{tabular}{|c|c|c|c|c|c|}
\hline Variables of internal resources & 1 & 2 & 3 & 4 & 5 \\
\hline 1 Intensity of internationalization & 1 & & & & \\
\hline 2 Financial resources for internationalization & $0.502^{* *}$ & 1 & & & \\
\hline 3 Human resources for internationalization & $0.501^{* *}$ & $0.687^{* *}$ & 1 & & \\
\hline 4 Physical resources for internationalization & $0.464^{* *}$ & $0.736^{* *}$ & $0.706^{* *}$ & 1 & \\
\hline 5 Information resources for internationalization & $0.502^{* *}$ & $0.496^{* *}$ & $0.507^{* *}$ & $0.578^{* *}$ & 1 \\
\hline
\end{tabular}

Source: own elaboration $(n=104)$.

Figures show that there is a significant difference in the evaluation of resources by companies of different sizes, since larger companies gave a more favourable description of their resources. Companies which were active in the international markets in general ('Does your firm run any international activities...?') also gave higher than average scores to particular factors than did those without international activities.

The correlation regarding attitude of owner/entrepreneur/manager to internationalisation is similar to the one of resources. The growing size of companies is closely correlated to the increase in motivation, knowledge and experience related to internationalisation. Similarly, active participation in internationalisation improves attitude of owner/entrepreneur/manager.

Internationalisation intensity and the attitude of owner/entrepreneur/manager are also in interdependence with each other. The weakest connection is experienced in the case of general business experience (Spearman's Rho=0.25, $p=0.011$ ). Similar to resources, the different factors of attitude are also in interdependence with each other (Table 2).

There are no significant divergences in the evaluation of sector characteristics by companies of different sizes. However, companies with international activities gave higher than the average scores to all factors than those without international activities. They believe the sector they operate in, experience a strong foreign competition. As a result of this, they think they operate in a strong competitive environment and face strong innovation challenges. Table 3 shows that there are two variables (Level of competitiveness in general, Level of innovation) that do not show significant correlation 
with the intensity indicator. Further items of the questionnaire provide bases for an objective evaluation of the role played by innovation in internationalisation ${ }^{2}$. Vulnerability towards internationalisation and intensiveness of foreign capital are only significant at 0.05 level.

Table 2. Relationship between foreign market entry modes and attitudes of owners, entrepreneurs and managers to internationalization

\begin{tabular}{|l|r|r|r|r|r|r|}
\hline \multicolumn{1}{|c|}{ Variables of Attitudes } & \multicolumn{1}{c|}{$\mathbf{1}$} & \multicolumn{1}{c|}{$\mathbf{2}$} & \multicolumn{1}{c|}{$\mathbf{3}$} & \multicolumn{1}{c|}{$\mathbf{4}$} & $\mathbf{5}$ & $\mathbf{6}$ \\
\hline $\mathbf{1}$ Intensity of internationalisation & 1 & & & & & \\
\hline 2 Motivation to go international & $0.449^{* *}$ & 1 & & & & \\
\hline 3 Cosmopolitanism and international openness & $0.433^{* *}$ & $0.765^{* *}$ & 1 & & & \\
\hline 4 Knowledge of international markets & $0.421^{* *}$ & $0.667^{* *}$ & $0.695^{* *}$ & 1 & & \\
\hline 5 Experience with international markets & $0.505^{* *}$ & $0.719^{* *}$ & $0.699^{* *}$ & $0.814^{* *}$ & 1 & \\
\hline 6 Professional business experience in general & $0.253^{*}$ & $0.438^{* *}$ & $0.478^{* *}$ & $0.522^{* *}$ & $0.516^{* *}$ & 1 \\
\hline
\end{tabular}

**. Correlation is significant at the 0.01 level (2-tailed); *. Correlation is significant at the 0.05 level (2-tailed). Source: own elaboration $(n=104)$.

There are no significant divergences in the evaluation of sector characteristics by companies of different sizes. However, companies with international activities gave higher than the average scores to all factors than those without international activities. They believe the sector they operate in, experience a strong foreign competition. As a result of this, they think they operate in a strong competitive environment and face strong innovation challenges. Table 3 shows that there are two variables (Level of competitiveness in general, Level of innovation) that do not show significant correlation with the intensity indicator. Further items of the questionnaire provide bases for an objective evaluation of the role played by innovation in internationalisation ${ }^{3}$. Vulnerability towards internationalisation and intensiveness of foreign capital are only significant at 0.05 level.

Similar to resources and attitudes, the different characteristics of the business industry also correlate with each other (Table 3).

Table 3. Relationship between foreign market entry modes and the basic characteristics of the business industry

\begin{tabular}{|c|c|c|c|c|c|c|}
\hline Variables of the business industry & 1 & 2 & 3 & 4 & 5 & 6 \\
\hline 1 Intensity of internationalization & 1 & & & & & \\
\hline 2 Vulnerability towards internationalization & $0.218^{*}$ & 1 & & & & \\
\hline 3 Level of competitiveness in general & 0.170 & $0.528^{* *}$ & 1 & & & \\
\hline 4 Intensiveness of foreign competitors & $0.405^{* *}$ & $0.466^{* *}$ & $0.514^{* *}$ & 1 & & \\
\hline 5 Intensiveness of foreign capital & $0.226^{*}$ & $0.414^{* *}$ & $0.387^{* *}$ & $0.754^{* *}$ & 1 & \\
\hline 6 Level of innovation & 0.054 & $0.313^{* *}$ & $0.254^{* *}$ & $0.476^{* *}$ & $0.536^{* *}$ & 1 \\
\hline
\end{tabular}

*. Correlation is significant at the 0.05 level (2-tailed); **. Correlation is significant at the 0.01 level (2-tailed). Source: own elaboration $(n=104)$.

\footnotetext{
${ }^{2}$ We experienced that the companies which have been committed to innovation in the past three years have higher intensity indices (0.33) than the non-innovative ones (0.24).

${ }^{3}$ We experienced that the companies which have been committed to innovation in the past three years have higher intensity indices (0.33) than the non-innovative ones (0.24).
} 
The variables which are in close correlation with each other enable us to explore the latent structure behind the 14 observed variables by a factor analysis. Within the framework of principal component analysis (PCA), the three factor groups under investigation (resources, attitudes, and sector characteristics) were jammed into two factors (Kaiser-Meyer-Olkin test $(\mathrm{KMO})=0.855$, total variance explained is $60.4 \%$ ). Table 4 shows the factor weight of the variables and the factor a particular variable is the most suitable for. It is clearly seen that variables measuring internationalisation resources and attitudes of owner/entrepreneur/manager to internationalisation constitute one factor. Thus, the subjective characteristics of owner/entrepreneur/manager (openness and motivation) are as critical resources of internationalization as objective ones (previous international experience, general business experience and possession of appropriate information). The other factor contains the variables that evaluate the basic characteristics of the business industry.

On the basis of the two elaborated factors, a hierarchical cluster analysis was performed and five groups of companies were identified. Two companies (Cluster 4 in Figure 5) turned out to be outsiders, even when a lower cluster number was selected. These two companies considered their resources to be over the average. However, they feel that the business environment they operate in fail to promote internationalisation. The rest of the paper investigates only clusters with more cases.

\section{Cluster 1: Successful world citizens}

Respondents of this cluster consider their resources to be high. They feel that business environment they operate in promotes their internationalisation. The intensity of their international activities is over the average. About $92.5 \%$ of them are present in the international market (their intensity indicator is 0.42 ). They employ 441 people on the average, so it is more than likely that they don't have any problems with acquiring the resources required for their international activities. They are mostly large and middle-sized companies operating in processing industry, construction and service industry. Their innovation activity is above the average. About $77.4 \%$ of respondents have implemented innovation in the last 3 years and $17 \%$ of them were involved in innovation at a global scale.

They are unlikely to require any direct support to promote internationalisation. However, every move that affects international rating of Hungary and shapes its image as well as the economic policy the country follows in supporting competitiveness of companies (cutting red tape) can indirectly contribute to successful internationalisation $(n=53)$.

\section{Cluster 2: Emerging way-out seekers}

Companies belonging to this cluster are mostly micro- and small-sized family enterprises (81.3\%) operating mainly in construction and service industry. Only half of them are present in international markets and are primarily engaged in importing. The majority of the firms in this cluster do not conduct any innovation activities (56.3\%). Even if they do, the scope of implemented innovation is limited (firm scale). They consider the competition in their sectors to be fierce and the foreign capital and foreign competitors to be dominating. However, they lack resources required for their successful internationalisation. In their case, internationalisation would be a way to move forward 
Table 4. Rotated component matrix of the factor analysis

\begin{tabular}{|l|c|r|}
\hline \multicolumn{1}{|c|}{ Variables } & $\begin{array}{c}\text { Factor 1: } \\
\text { Internal } \\
\text { Resources }\end{array}$ & $\begin{array}{c}\text { Factor 2: Driving } \\
\text { forces of the } \\
\text { industry }\end{array}$ \\
\hline Knowledge of international markets & 0.882 & 0.020 \\
\hline Experience with international markets & 0.858 & 0.090 \\
\hline Human resources for internationalization & 0.811 & 0.176 \\
\hline Information resources for internationalization & 0.803 & 0.163 \\
\hline Cosmopolitanism and international openness & 0.769 & 0.243 \\
\hline Motivation to go international & 0.766 & 0.342 \\
\hline Physical resources for internationalization & 0.757 & 0.348 \\
\hline Professional business experience in general & 0.593 & 0.091 \\
\hline Financial resources for internationalization & 0.586 & 0.134 \\
\hline Intensity of foreign competitors & 0.201 & 0.839 \\
\hline Intensity of foreign capital & 0.123 & 0.837 \\
\hline Level of innovation & -0.024 & 0.729 \\
\hline Vulnerability to internationalization & 0.322 & 0.585 \\
\hline Level of competitiveness in general & 0.202 & 0.571 \\
\hline
\end{tabular}

Source: own elaboration $(n=104)$.

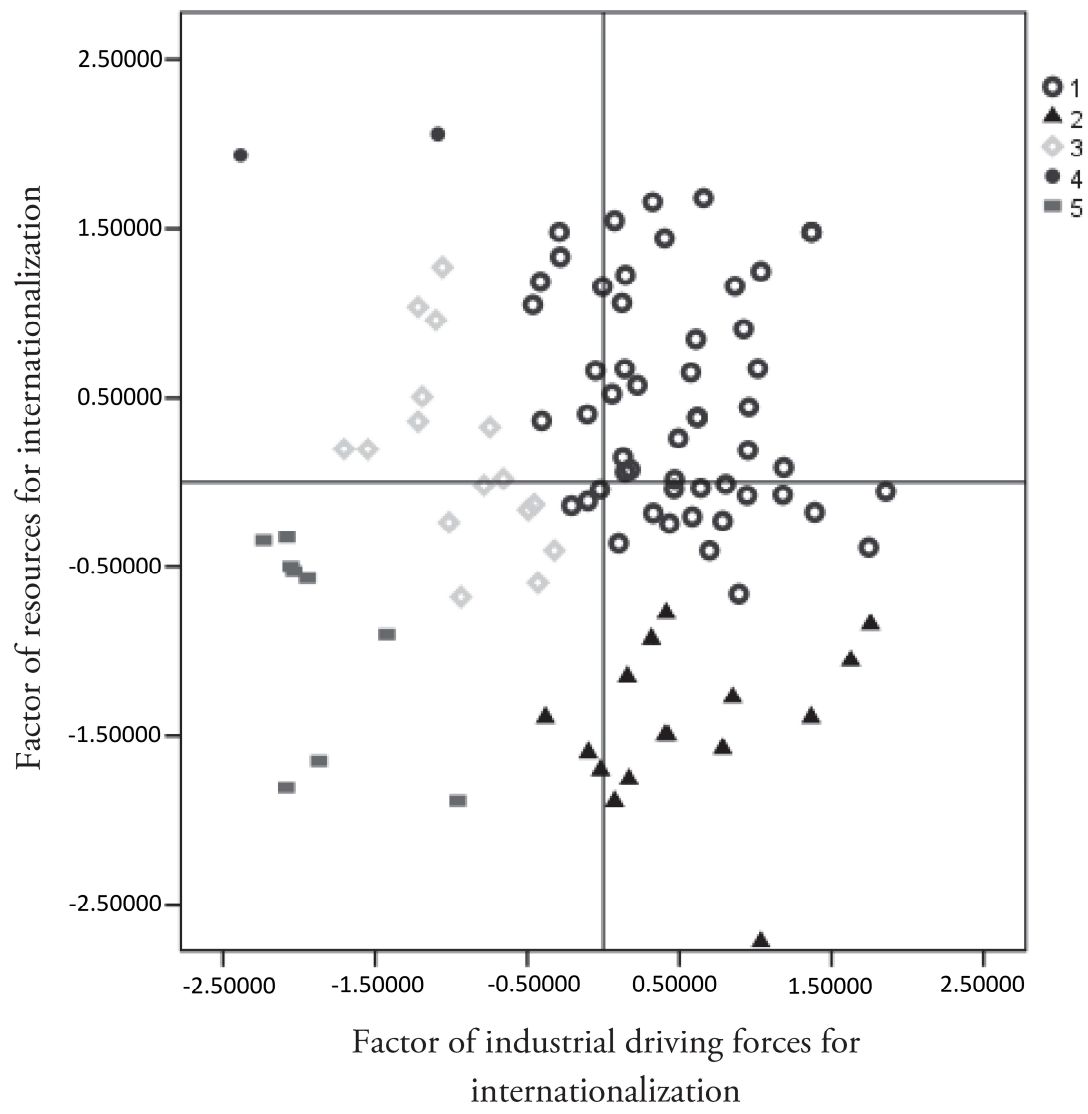

Figure 5. Company clusters

Source: own elaboration. 
and to increase their competitiveness, since they experience strong international competition even in national markets because of the characteristics of the business industry, which the firms operate in $(n=16)$.

The factor analysis highlighted the fact that it is necessary to own physical resources and to have an access to appropriate information, but it is insufficient. The attitude of the owner/entrepreneur/manager to internationalisation should be improved as well so that they will be able to break into international markets. The channels leading to increase their subjective and objective resources need to be identified.

\section{Cluster 3: Ordinary people}

Enterprises making up this cluster are primarily small- and middle-sized service providers. They feel that their available resources for internationalisation are average and the sector they operate in fails to promote their internationalisation. However, $75 \%$ are active in international markets with different entry modes (contractual, investment, exporting and importing modes). They are also active in innovation, $75 \%$ of companies (12 firms) implemented some innovation in the last 3 years. However, only one respondent reported innovation at a global scale. Taking into consideration their intensity indicator of 0.32 , they seem to utilize the available resources $(n=16)$.

\section{Cluster 5: Local patriots}

Only 9 enterprises make up this group: 4 large companies and 5 small- and middle-sized enterprises. All but one operate only in the national market. They have little opportunities to break into international markets. They lack subjective and objective resources for internationalisation. In addition, the characteristics of their business industry they operate in fail to contribute to their becoming international $(n=9)$.

\section{CONCLUSIONS}

This paper analyses corporate internationalisation by applying an intensity indicator. The analysis concentrated on three areas and investigated the role of resources, managerial attitudes and industrial driving forces in internationalisation process. According to technical literature, these factors relate positively to international activity. This paper has analysed their effect on the internationalisation intensity. Findings show that the more resources for the internationalization process a company has, the more complex solutions it applies. The attitude of owner/entrepreneur/manager to internationalisation (motivation, approach and knowledge) shows the same results. Driving forces of the company's sector (intensiveness of foreign competitors and foreign capital, vulnerability towards internationalisation) also affect modes of international activities.

By applying a factor analysis we came to the conclusion that the attitude of corporate owner/entrepreneur/manager to internationalisation is as critical resource in terms of internationalisation processes as other objective resources owned by companies. The obtained results show that providing physical resources and access to appropriate information is necessary, but not sufficient. The attitude of the owner/entrepreneur/manager to internationalisation should be improved as well, so that they will be able to appear and operate successfully in international markets. Giving the right place to subjective matters in promoting internationalisation and giving more 
support apart from financial ones in this area (with coaching, consulting, etc.) may contribute to the increase in corporate participation in different support programs.

By conducting a cluster analysis, we managed to identify some specific groups of companies and determine which companies require external assistance for fostering their internationalisation. The cluster analysis showed that companies need tailor-made support in their internationalisation process which should depend on their preparedness and the characteristics of their business industry.

\section{REFERENCES}

Abrahamczik, C. (2012). Die erfolgreiche Internationalisierung kleiner und mittlerer Unternehmungen. München: Reiner Hampp Verlag.

Anderson, E., Gatignon, H. (1986). Modes of foreign entry: a transaction cost analysis and propositions. Journal of International Business Studies, 17(3), 1-26.

Antalóczy, K., \& Éltető, A. (2002). A Magyar vállalatok nemzetköziesedése - indítékok, hatások és problémák. Közgazdasági Szemle, 49(2), 158-172.

Barkema, H., Bell, J.H., \& Pennings, J.M. (1996). Foreign entry, cultural barriers, and learning. Strategic Management Journal, 17(2), 151-166.

Clerq, D., \& Bosma, N. (2004). Why are some firms more internationally committed than others? The role of knowledge, firm development stage and optimism. EIM, SCALES-paper N200408.

Daszkiewicz, N., \& Wach, K. (2012). Internationalization of SMEs: Context, Models and Implementation. Gdańsk: Gdańsk University of Technology Publishers.

Dimitratos, P. (2002). The firm's location in the home country and internationalisation: some evidence from Greek smaller firms. Intereconomics, 37(2), 91-100.

EC (2010). Internationalisation of European SMEs, Final report. EIM Business \& Policy Research. European Commission - DG Enterprise and Industry.

Erikkson, K., Johanson, J., Majkgard, A., \& Sharna, D.D. (1997). Experimental knowledge and cost in the internationalization process. Journal of Business Studies, 28(2), 337-360.

Erramilli, M.K. (1991). The Experience Factor in Foreign Market Entry Behavior of Service Firms. Journal of International Business Studies, 22(3), 479-501.

Eurofound (2012). Born global: The potential of job creation in new international businesses. Luxembourg: Publications Office of the European Union.

Granovetter, M. (2005). The impact of social structure on economic outcomes. Journal of Economic Perspectives, 19(1), 33-50.

Gubik, S.A. (2011). A comparison of experts' and entrepreneurs' opinions on international business activity. Theory Methodology and Practice, 7(2), 47-54.

Hitt, M.A., Bierman, L., Uhlenbruck, K., \& Shimizu, K. (2006). The importance of resources in the internationalization of professional service firms: the good, the bad and the ugly. The Academy of Management Journal, 49(6), 1137-1157.

Horská, E., \& Krasnodębski, A. (2009). The selected theoretical and practical viewpoints to managing cultural diversity in the international business. Agricultural Economics-Czech, 55(8), 368-374.

Johanson, J., \& Vahlne, J.E. (1977). The internationalization process of the firm - a model of knowledge development and increasing foreign market commitment. Journal of International Business Studies, 8(1), 23-32. 
Johanson, J., \& Vahlne, J.E. (1990). The mechanism of internationalisation. International Marketing Review, 7(4), 11-24.

Johanson, J., \& Wiedersheim-Paul, F. (1975). The internationalization of the firm. Four Swedish cases. Journal of Management Studies, 12(3), 305-323.

Perliz, M. (2004). Internationales Management. Stuttgart: Lusius \& Lucius Verlaggesellschaft.,

Rasmussen, E., \& Madsen, T.K. (2002). The Born Global Concept. 28th ElBA Conference in the special session on SME internationalization and born globals - different European views and evidence. Retrieved on January 13, 2013, from http://www.aueb.gr/deos/EIBA2002.files/PAPERS/S4.pdf

Reid, S.D. (1981). The decision-maker and export entry and expansion. Journal of International Business Studies, 12(2), 101-112.

Stackelberg, H. (1952). The Theory of the Market Economy. London: W. Hodge \& Co.

Szerb, L., \& Márkus, G. (2008). Nemzetköziesedési tendenciák a kis- és közepes méretű vállalatok körében Magyarországon a 2000-es évek közepén. Vállalkozás és Innováció, 2(2), 36-58.

\section{Authors}

A.S. Gubik prepared the literature review and the statistics calculations, while S. Karajz created the database and took part in the idea generation.

\section{Andrea S. Gubik}

Associate professor of the Institute of Economic Theory at the Faculty of Economics of the University of Miskolc (Hungary).

\section{Sándor Karajz}

Associate professor and the head of the Institute of Economic Theory at the Faculty of Economics of the University of Miskolc (Hungary).

\section{Correspondence to:}

Andrea S. Gubik, PhD

University of Miskolc

Faculty of Economics

3515 Miskolc-Egyetemváros

Hungary

getgubik@uni-miskolc.hu 
